\title{
Influence of surface modification to stainless steel on initial Streptococcus mutans adhesion and antibacterial acivity
}

\author{
Nurhaerani*, Rossje Rosita Oewen*, Yetty Herdiyati* \\ *Department of Pedodontics Faculty of Dentistry Universitas Padjadjaran
}

\section{ABSTRACT}

Introduction: Stainless steel is one of the most frequently used material in pediatric dental clinic for stainless steel crown, bracket, molar band and archwire. The purposes of this study were to evaluate the surface characteristic (chemichal composition, hydrophobicity, fluoride release), antibacterial activity of modified stainless steel and to evaluate the initial adhesion S. mutans on the surface of modified stainless steel. Methods: This study was an experimental laboratory. Sample used in this study was Stainless steel which modified with the plasma based fluorine ion implantation. The stainless steel which was fluorine ion implanted by CF4 gas was washed in a ultrasonic bath containing distilled water for 10 minute. The modified stainless steel materials were washed in an ultrasonic bath containing distilled water for 10 minute. Stainless steel material was incubated at $37^{\circ} \mathrm{C}$ in $2 \mathrm{ml}$ of BHI broth containing $\mathrm{S}$. mutans with concentration $2 \times 107 \mathrm{CFU} / \mathrm{ml}$. After 48 hours incubation, a $0.5 \mathrm{ml}$ of solution was immediately transferred into $4.5 \mathrm{ml}$ of PBS (-) and diluted. A 100 pi of diluted solution was plated on BHI agar. After 48 hours culture at $37^{\circ} \mathrm{C}$, the number of colonies was counted. The numbers of fluorine ion implanted material and fluorine ion non-implanted control were ten, respectively. Results: XPS analysis showed the presence of fluorine and chromic fluoride until second layer. The contact angle of modified stainless steel was significantly increased A small amount of fluorine ion released from surface of modified stainless steel was detected until the second day. Fluorine ion implanted of stainless steel was significantly decreased the initial adhesion and increased the antibacterial activity. Conclusion: The adhesion of S. mutans on the surface of stainless steel for 4 hours incubation is shown in Figure 11. Fluorine ion implanted stainless steel showed less bacterial adhesion than fluorine ion non- implanted control $(p<0.001)$.

Keywords: Surface modification, stainless steel, Streptococcus mutans.

\section{INTRODUCTION}

Stainless steel is one of the most frequently used material in pediatric dental clinic for stainless steel crown, bracket, molar band and archwire. Stainless steel crown has been shown to provide the most durable restorative material for primary molars. ${ }^{1-4}$ Most metallic brackets used in orthodontic therapy made from stainless steel
(SUS) with the appropriate physical properties and available as types 304, 306 and 17-4 PH SS (OH KT). ${ }^{5}$ The bracket material could play a role in the degree of bacterial adhesion and plaque accumulation as well as in the risk of caries development. Metallic orthodontic brackets have been found to induce specific changes in the oral environment such as reduced levels of $\mathrm{pH}$, increased plaque accumulation, and 
elevated S. mutans colonization. Preventing these problems has been an important concern for pedodontist and orthodontist, because the lesions are unaesthetic, unhealthy and potentially irreversible. Streptococcus mutans has been strongly implicated as a causative organism of dental caries and is frequently isolated from human dental plaque. ${ }^{6-12}$ There are at least two methods for inhibiting the formation of microbial plaque. The first method is to inhibit the initial adhesion of oral bacteria. The second method is to inhibit the colonization of oral bacteria which involves surface antibacterial activity. ${ }^{13-15}$

In recent years many efforts have been made to improve the properties and biocompatibility metals such as titanium and stainless steel. Plasma surface modification (PSM) as an economical and effective material processing technique is gaining popularity in the biomedical field. It is possible to change continuum of the chemical composition and properties such as wettability, adhesion, dyeability, refractive index, hardness, chemical inertness, lubricity and biocompatibility of material surfaces. ${ }^{16}$ In the recent years, Plasma Based Ion Implantation (PBII) has become a great interest for modify the surfaces of biomaterials due to possibility of surface with complicated shape, possibility of thick material and excellent into material. ${ }^{17,18}$ Compared to conventional ion implantation, the plasma based ion implantation facility is smaller, less expensive, simpler to maintain and operate, and more compatible with in house operation as opposed to the outside service facility mode operation which is prevalent at present in the ion beam processing industry. ${ }^{19-23}$ Some researchers carried out surface modification by ion implantation. However, they mostly concentrated on the corrosion, wear and fatigue resistance properties of titanium. Several research groups improved the biocompatibility by implanting $\mathrm{Ca2}+$ and $\mathrm{Mg} 2+$ into titanium and alumina, respectively. ${ }^{24}$ Fluoride (the ionic form of fluorine) is excellent against tooth decay. Fluoride covers teeth with thin layers, so it protects from forming cavities. Since fluorine is one of the reactive element in the periodic table, it makes a lot of compounds with almost every element. Fluoride is able to act directly to bacteria.As an enzyme inhibitor, and another mode of action to bacteria involves formation of metal-fluoride complexes. ${ }^{25,26}$ Bacterial adhesion to biomaterial surface is an important step in the pathogenic infection. Surface characteristics of biomaterials are reported to influence bacterial adhesion in vitro. Bacterial adhesion is very complicated process that is affected by many factors, such as the environmental factors (temperature, time period of exposure and bacterial concentration), the bacterial characteristics (bacterial hydrophobicity and bacterial surface charge) and the surface characteristics of the biomaterials (chemical composition, surface charge, hydrophobicity and surface roughness). ${ }^{27,28} \mathrm{In}$ order to determine the surface characteristic of the modified stainless steel, XPS analysis, fluoride release and contact angle measurement were done. The purposes of this study were to evaluate the surface characteristic (chemichal composition, hydrophobicity, fluoride release), antibacterial activity of modified stainless steel and to evaluate the initial adhesion S. mutans on the surface of modified stainless steel.

\section{METHODS}

This study was an experimental laboratory study. Sample used in this study was Stainless steel which modified with the plasma based fluorine ion implantation. Stainless steel (SUS316L) polished like mirror Size $10 \mathrm{~mm} \times 10 \mathrm{~mm} \times 1 \mathrm{~mm}$ Schematic model of research design shown in figure 1 .

Principle of plasma based ion implantation is shown in Figure 2. The materials are immersed into plasma and surrounded by high density plasma and pulse-biased to a high negative potential relative to the chamber wall. Ions generated in the overlying plasma are accelerated across the sheath which is formed around the material and implanted into the surface of the materials. ${ }^{65}$

Stainless steel plates with size $10 \mathrm{mmx}$ 10nunx 1 nun were modified by plasma based ion implantation in Ion Engineering Research Institute Co., Osaka, Japan. Stainless steel, SUS3 $16 \mathrm{~L}$ (Fe 65.67wt\%, Cr 17.00wt\%, Ni 13.00wt\%, Mo 2.40wt\%, Mn $1.40 \mathrm{wt} \%$, C $0.03 \mathrm{wt} \%$, Si $0.50 \mathrm{wt} \%$ ) was produced by Daido steel co., Ltd., Nagoya, Japan. Fluorine gas for plasma based ion implantation was CF4 gas. The condition of plasma based fluorine ion implantation is shown in Figure 3. As a control, non-fluorine-ion implanted stainless steel was 


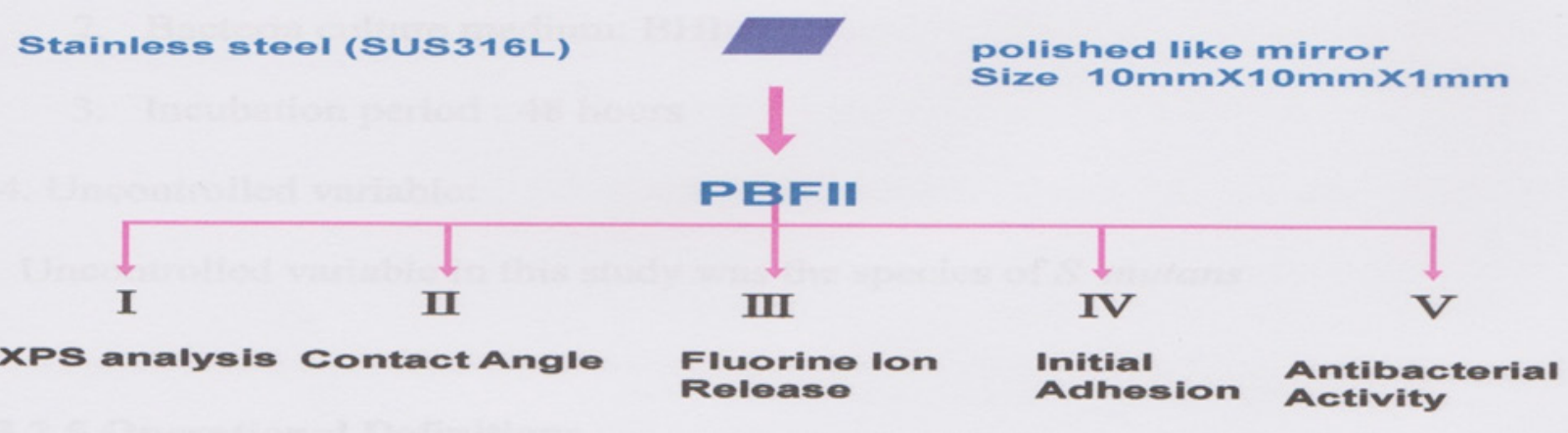

Figure 1. Schematic model of research design

used. The stainless steel which was fluorine ion implanted by CF4 gas was washed in a ultrasonic bath (J.M. Ultrasonic Cleaner SUW-50d, j. Moritis Corporation) containing distilled water for 10 minute. After washing procedures, the material was dried in room temperature.

The modified stainless steel materials were washed in an ultrasonic bath (J.M. Ultrasonic Cleaner SUW-50D, J. Morita Corporation) containing distilled water for 10 minute. After washing procedures, the material was dried in room temperature. A drop a distilled water was carefully placed on each slightly dried, prepared surface, and contact angle was measured using the sessile drop technique with contact angle meter (CA-DT, Kyowa Kaimenkagaku Co. Ltd). Five points per material were measured. The total numbers of fluorine ion implanted materials and fluorine ion non-implanted control were ten, respectively. specific electrode (ionplus Sure-Flow Fluoride, 9609 BN; Orion Research Inc., Beverly, MA, USA) connected to an expandable ion analyzer (model 702A; Orion Research Inc., Boston, MA, USA). Calibration of the analyzer was performed before the testing with standard solution of 0.1 , 0.5 and $1.0 \mathrm{ppm}$ fluorine ion.

\section{Initial adhesion and antibacterial activity}

Into a petri dish, $20 \mathrm{ml}$ of BHI broth and 200121 of S. mutans with concentration $4 \times 108 \mathrm{CFU} / \mathrm{ml}$ were poured and stainless steel material was placed with the fluorine ion implanted surface upward. After 4 hours incubation at $37^{\circ} \mathrm{C}$, the material was removed from the petri dish and washed three times with phosphate-buffered saline without calcium and magnesium (PBS (-)). The material was then placed in a tube containing $2 \mathrm{ml}$ of PBS (-) and the tube was sonicaced (Dentcraft Ultrasonic

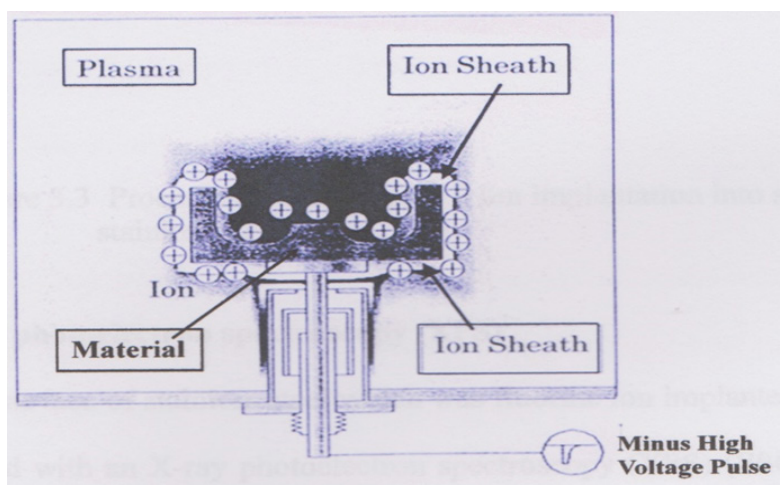

Figure 2. Principle of plasma based ion implantation

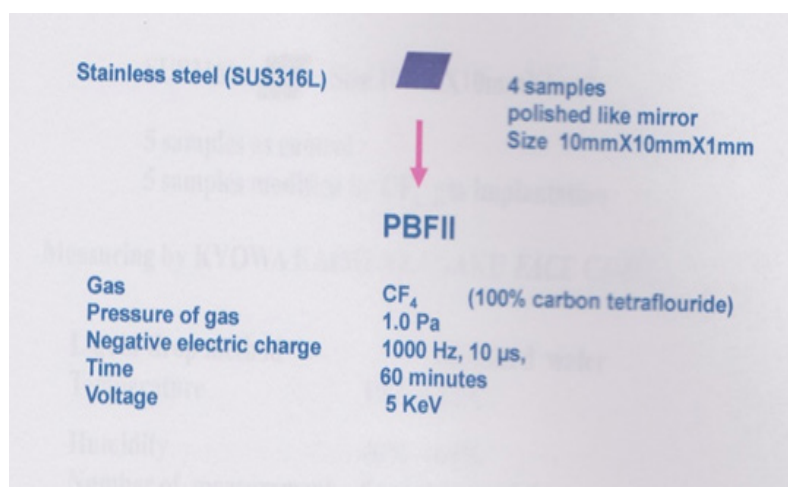

Figure 3. Process and condition of $F$ ion implantation into surface of stainless steel

A Initial Adhesion
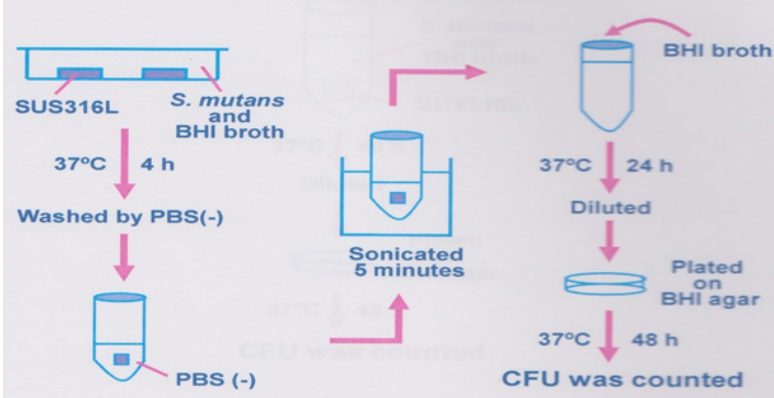

Figure 4. Schematic model of initial adhesion 


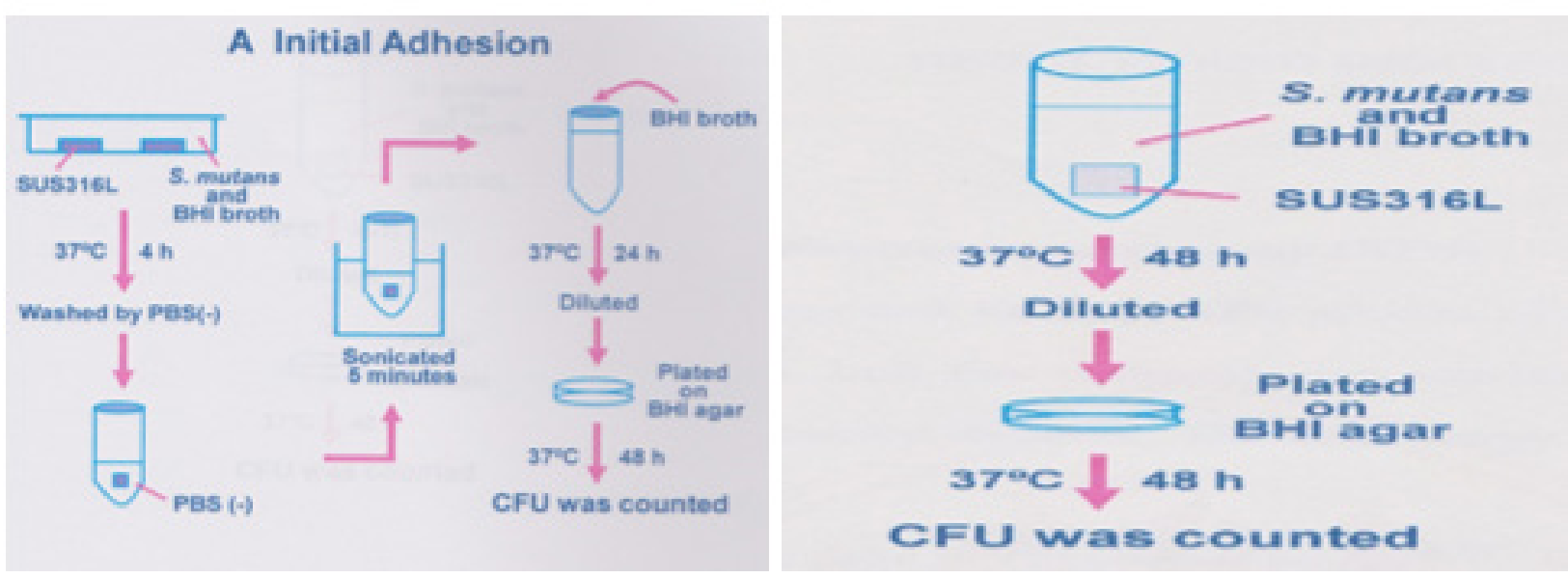

Figure 5. Schematic model of antibacterial activity

3800 N, Yoshida Corporation, Tokyo, Japan) for 5 minutes. The material was removed from the tube and $10 \mathrm{ml}$ of $\mathrm{BHI}$ broth was added into the tube. After 24 hours incubation at $37^{\circ} \mathrm{C}, 0.5 \mathrm{ml}$ of solution was immediately transferred into $4.5 \mathrm{ml}$ of PBS (-) and diluted. A 100 pi of diluted solution was plated on $\mathrm{BHI}$ agar. After 48 hours culture at $37^{\circ} \mathrm{C}$, the number of colonies was counted (Figure 3.6). The numbers of fluorine ion implanted material and fluorine ion non-implanted control were ten, respectively.

\section{Antibacterial activity}

Stainless steel material was incubated at $37^{\circ} \mathrm{C}$ in $2 \mathrm{ml}$ of $\mathrm{BHI}$ broth containing $\mathrm{S}$. mutans with concentration $2 \times 107 \mathrm{CFU} / \mathrm{ml}$. After 48 hours incubation, a $0.5 \mathrm{ml}$ of solution was immediately transferred into $4.5 \mathrm{ml}$ of PBS (-) and diluted. A 100 pi of diluted solution was plated on $\mathrm{BHI}$ agar. After 48 hours culture at $37^{\circ} \mathrm{C}$, the number of colonies was counted. The numbers of fluorine ion implanted material and fluorine ion non-implanted control were ten, respectively. The statistical analysis was performed with student $t$ test using computer software (SPSS 10.0 for windows)

\section{RESULTS}

\section{$X$-ray photoelectron spectroscopy (XPS)}

$\mathrm{F} 1 \mathrm{~s}, \mathrm{Cr} 2 \mathrm{p}_{3 / 2}$ and $\mathrm{Fe} 2 \mathrm{p}_{3 / 2}$ XPS spectra of stainless steel SUS $316 \mathrm{~L}$ are shown in Figure 4.1. Left side is fluorine ion non-implanted control and right side is fluorine ion implanted material. Binding energy by other works is shown in Table 1 .
Table 1. Binding energy $(\mathrm{eV})$ by other works ${ }^{29,30}$

\begin{tabular}{ccc}
\hline Compound & Binding Energy & Reference \\
\hline $\mathrm{F}$ & 685.5 & Shimadzu Co. $\left.^{*}\right)$ \\
Metal cr & 574.3 & ${\text { Briggs D et al. }{ }^{66}}$ Briggs D et al. $^{66}$ \\
$\mathrm{Cr}_{2} \mathrm{O}_{3}$ & 574.3 & Hanamoto K et al 1.67 \\
$\mathrm{Crf2}$ & 578.2 & Brigss D et al." \\
Metal Fe & 706.95 & Brigss d et al." \\
$\mathrm{Fe} 03$ & 710.9 & Brigss D et al.” \\
FeF2 & 711.4 & \\
\hline
\end{tabular}

F 1s peak position was observed at $685.3 \mathrm{eV}$ on the surface layer and at $685.5 \mathrm{eV}$ on the second layer (Figure 4.1b).

Chemically shifted peaks of $\mathrm{Cr} 2 \mathrm{p}_{3 / 2}$ were observed in the higher binding energy region on the surface and the second layers (Figure 8d). Chemically shifted peak of $\mathrm{Fe} 2 \mathrm{p}_{3 / 2}$ was observed in the higher binding energy region on the surface layer (Figure 8). ${ }^{29,30}$

\section{Contact angle}

The contact angle of stainless steel is shown in Figure 9. Fluorine ion implanted stainless steel surface showed significantly higher contact angle than fluorine ion non-implanted control $(p<0.001)$.

\section{Fluorine ion release}

Fluorine ion release from the surface of fluorine ion incianted stainless steel is shown in Figure 10. A small amount of fluorine ion mimed until the second day. After the third day, fluorine ion was not detected. 


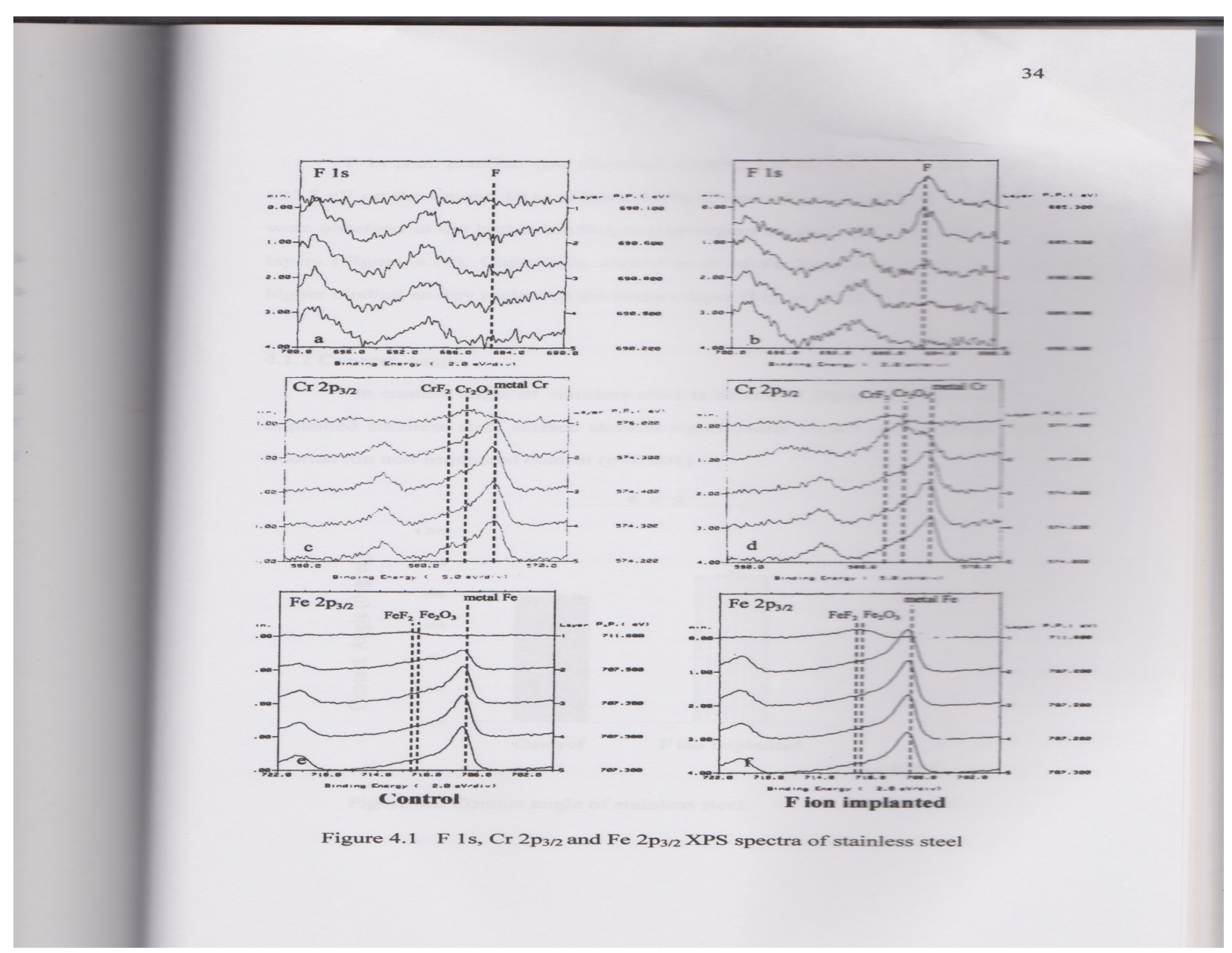

Figure 6. F1s, $\mathrm{Cr} 2 \mathrm{p} 3 / 2$ and Fe $2 \mathrm{p} 3 / 2$ XPS spectra of stainless steel

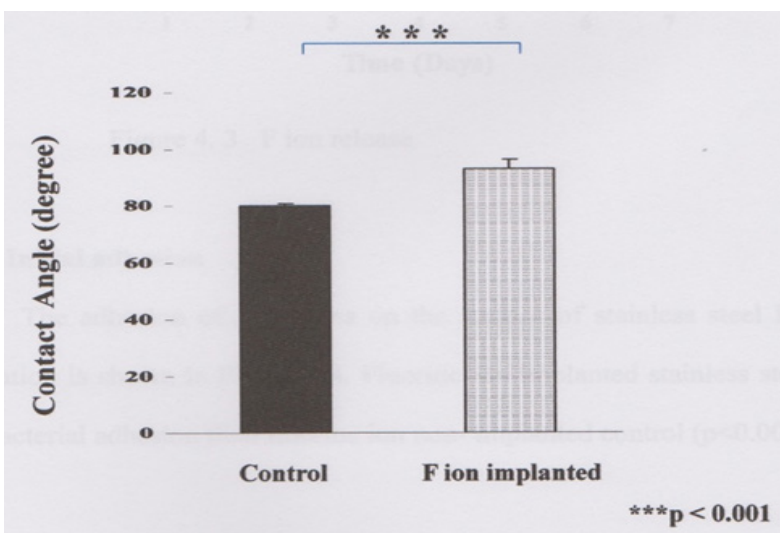

Figure 4.2 Contact angle of stainless steel

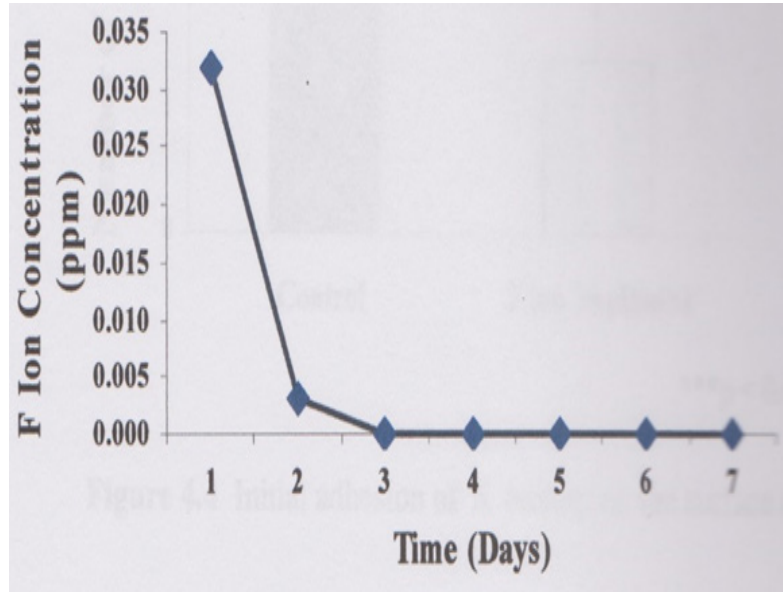

Figure 8. F ion release

\section{Antibacterial activity}

The colony of S. mutans on BHI agar for antibacterial activity test is shown in The number of $\mathrm{CFU} / \mathrm{ml}$ is shown in Figure 12. Fluorine ion implanted stainless steel showed lower number of CFU than fluorine ion non-implanted control $(p<0.001)$. 


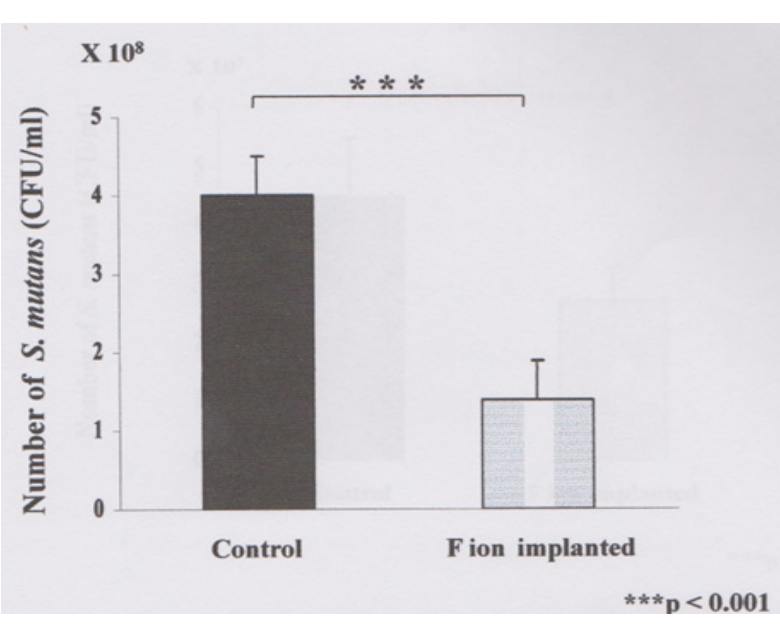

Figure 9. Initial adhesion of S. mutans on the surface of stainlees steel

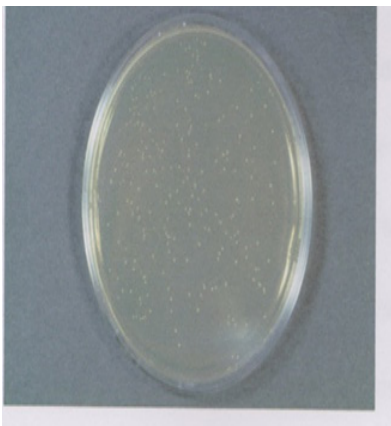

Control

Figure 4.6. Colony of S. mutans on BHI agar for antibacterial activity test of stainless steel

Figure 10. Colony of S.mutans on BHI agar for antibacterial activity test of stainless steel

\section{DISCUSSION}

In this study, mixed gas of CF4 gas were used. Fluorine ion was implanted into stainless steel. In XPS analysis, the binding energy of chromic oxide $(\mathrm{Cr}-03)$ and chromic fluoride ( $\mathrm{CrF} 2)$ are reported to be 576.6 eV66 and $578.2 \mathrm{eV} .6$ - respectively. ${ }^{29}$ It suggests that the shifted peak shown in the present study (Figure 5-d) was due to $\mathrm{Cr} 2 \mathrm{O} 3$ and CrF2. The binding energy of iron fluoride (FeF2) and iron oxide (Fe2O3) are reported to be 711.4 $\mathrm{eV}$ and $710.9 \mathrm{eV}$, respectively. ${ }^{30}$ Iron oxide (Fe2O3) was detected on the surface of fluorine implanted stainless steel. Over the second layer, the peak is close to metal iron. Compared with fluorine ion non-implanted control, spectra shifts did not change. This finding suggests that fluorine does not combine with iron. In the present study, the contact angle of fluorine implanted stainless steel was significantly increased. The higher contact angle is, the more hydrophobic the solid surface becomes. As the contact angle increases, the wettability decreases or becomes hydrophobic. ${ }^{31,32}$

The contact angle can be used to calculate the surface free energy of a solid surface. According to interfacial thermodynamics, high surface free energy strains, such as S. mutans, should adhere preferentially to hydrophilic substrata. In accordance to this hypothesis is the finding of this present study that initial adhesion of S. mutans on the surface of fluorine ion implanted stainless steel significantly decreased was suggested due to significant increase of contact angle. A small amount of fluorine ion released from the surface of fluorine ion implanted stainless steel within 24 hours and an extremely small amount of fluorine ion was detected until two days, but was not detected after three days. This finding suggested that the small amount of fluorine ion released not from the inside but from the fluorine ion contaminated surface of stainless steel. Initial (4 hours) adhesion of S. mutans on the surface of stainless steel was evaluated.

The initial adhesion on the fluorine ion implanted stainless steel decreased significantly compared with fluorine ion non-implanted control. This finding may be due to increase of contact angle as described as above, and antibacterial activity as described as follows. In the present study, the fluorine ion implanted stainless steel showed the antibacterial activity. There are two possible explanations for antibacterial mechanism of the $r$ implanted materials. One is the action of the fluorine ions and the other is actions of metal fluoride complexes.

Fluorine ion released from fluoride can affect bacterial metabolisme as an enzyme inhibitor, for example for the glycolytic enzyme enolase. The metal fluoride complexes are responsible for fluoride inhibition of proton-translocating F-ATPase and are thought to act by mimicking phosphate to form complexes with ADP at reaction centers of the enzyme. ATPase plays an important role in the maintenance of the intracellular $\mathrm{pH}$ by pumping out protons; inhibition of this enzyme disrupts the bacterial metabolism and the acid uric capability of $S$. mutans. ${ }^{33-5}$ Considering the results from X-ray photoelectron spectroscopy, XPS spectra of 
fluorine implanted stainless steel showed chromic fluoride complexes. This metal fluoride complexes might be responsible for antibacterial activity.

\section{CONCLUSION}

Surface modification to stainless steel of initial adhesion on the fluorine ion implanted stainless steel decreased significantly compared with fluorine ion non-implanted control. initial adhesion of S. mutans on the surface of fluorine ion implanted stainless steel significantly decreased was suggested due to significant increase of contact angle. Fluorine ion implanted stainless steel showed less bacterial adhesion than fluorine ion non- implanted control.

\section{REFERENCES}

1. Lee JK. Restoration of primary anterior teeth: review of the literature. Pediatr Dent 2002;24: 506-510.

2. Roberts JF, Attari N, Sherriff M. The survival of resin modified glass ionomer and stainless steel crown restorations in primary molars, placed in a specialist pediatric dental practice. BDJ2005;198: 427-431.

3. Seale NS. The use of stainless steel crowns. Pediatr Dent 2002;24: 501-505.

4. Randall RC. Preformed metal crowns for primary and permanent molar teeth: review of the literature. Pediatr Dent 2002;4: 489500.

5. Oh KT, Choo SU, Ki KM, Kim KN. A stainless steel bracket for orthodontic application. Eur J Orthod 2005;27: 237-244.

6. Papaioannu W, Gizani S, Nassika M, Kontou C, Nakau M. Adhesion of Streptococcal mutans to different types Brackets. Angle Orthodontist 2007;77: 1090-1095.

7. Satou J, Fukunaga A, Satou N, Shintani H, Okuda K. Streptococcal adherence on various restorative materials. J Dent Res 1988;67: 588- 591.

8. Balenseifen JW, Madonia JV. Study of dental plaque in orthodontic patients. J Dent Res 1970;49: 320-324.

9. Steinberg D, Eyal S. Initial biofilm formation of Streptococcus sobrinus on various orthodontics appliances. J Oral Rehabil 2004;31: 1041-1045.
10. Eliades T, Eliades G, Brantley WA. Microbial attachment on orthodontic appliances: Wettability and early pellicle formation on bracket materials. Am J Orthod Dentofac Orthop 1995;108: 351-360.

11. Rosenbloom RG, Tinanoff N. Salivary Streptococcus mutans levels in patients before, during and after orthodontic treatment. Am J Orthod Dentofac Orthop 1991;100: 35-37.

12. Forsberg CM, Brattstrom V, Maimberg E, Nord CE. Ligature wires and elastomeric rings: two methods of ligation, and their association with microbial colonization of Streptococcus mutans and lactobacilli. Eur J Orthod 1991;13: 416-420.

13. Gorelick L, Geiger AM, Gwinnet AJ. Incidence of spot formation after bonding and banding. Am J Orthod 1982;81: 93-98.

14. Ogaard B. Prevalence of white spot lesions in 19 year olds: a study on untreated and orthodontically treated persons 5 years after treatment. Am J Orthod Dentofac Orthop 1989;96: 423-427.

15. Vandevska-Radunovic V. Neural modulation of inflammatory reactions in dental tissues incident to orthodontic tooth movement. A review of the literature. Eur. I Orthod 1999;21: 231-247.

16. Yamaguchi $M$, Kasai $K$. Inflammation in periodontal tissues in response to mechanical forces. Arch Immunol Ther Exp 2005;53: 388 398.

17. Chu PK, Chen JY, Wang LP, Huang N. Plasmasurface modification of biomaterials. Mater Sci Eng R 2002;36: 143-206.

18. Kuze E, Teramoto T, Yukimura K, Maruyama T. Contact angle of water on chromium nitride thin flu prepared on three-dimensional materials by chromium plasma-based ion implantation. Surf Coat Technol 2000;158159, 577-581.

19. Conrad JR, Radtke JL, Dodd RA, Worzala FJ, Tran NC. Plasma source ion- implantation technique for surface modification of materials. J Appl Phys 1987;62: 4591-4596.

20. Yankov RA, Mandl S. Plasma immersion ion implantation for silicon processing. Ann Phys (Leipzig) 2001;4:279-298.

21. Watanabe T, Yamamoto K, Tsuda 0, Tanaka, A, Koga, Y. Synthesis of amorphous carbon films 
by plasma-based ion implantation using ECR plasma with a mirror field. Surf Coat Technol 2002;156: 317-321.

22. Paulus M, Stals L, Rude U, Rauschenbach B. Two-dimensional simulation of plasma based ion implantation. J Appl Phys 1998;85: 761766.

23. Yang YZ, Tian JM, Tian JT, Chen ZQ. Surface modification of titanium through amino group implantation. Biomed Mater Res 2001;55: 442444.

24. Troia MGJr, Henriques GE, Nobilo MA, Mesquito MF. The effects of thermal cycling on the bond strenght of low-fusing porcelain to commercially pure titanium and titaniumaluminium-vanadium alloy. Dent Mater 2003;19: 790-796.

25. Al Hussaini I, Al Wazzan KA. Effect of surface treatment on bond strength of low-fusing porcelain to commercially pure titanium. J Prosthet Dent 2005;94: 350-356.

26. Marquis RE. Antimicrobial actions of fluoride for oral bacteria. Can J Microbiol 1995;41: 955-964.

27. Yoshinari M, Oda Y, Kato T, Okuda K. Influence of surface modifications to titanium on antibacterial activity in vitro. Biomaterials 2001;22: 2043-2048.

28. An YH, Friedman RJ. Concise review of mechanisms of bacterial adhesion to biomaterial surface. J Biomed Mater Res (Appl Biomater) 1998;43: 338-48.

29. Briggs D, Seoh MP. Auger and X-ray spectroscopy. Practical Surface Analysis second edition 1990;1: 606-607.

30. Hanamoto K, Sasaki M, Miyashita T, KidoY, Nakayama Y, Kawamoto Y, et.al. Effect of fluorine ion implantation on the microstructure and microhardness of AISI 440C stainless steel. Nucl Instrand Meth Phys Res B 1997;129: 228232.

31. Sipahi C, Anil N, Bayramli E. The effect of acquired salivary pellicle on the surface free energy and wettability of different denture base materials. Journal of dentistry 2001;29: 197-204.

32. Quirynen $M$, Marechal $M$, Busscher $\mathrm{HJ}$, Weerkamp AH. Darius PL. van Steenberghe D. The influence of surface free energy and surface roughness on early plaque formation. Journal clinical periodontology 1990;17: 138144.

33. Hamilton IR. Biochemical effects of fluoride on oral bacteria. Journal Dental Research 1990;69(Spec.Iss): 660-667.

34. Hayacibara MF, Rosa OPS, Koo H, Tones SA, Costa B, Cury JA. Effects of fluoride and aluminum from ionomeric materials on $S$. mutansbiofilm. Journal of dental research 2003;82: 267-271.

35. Verbeeck RMH, De Maeyer EAP, Marks LAM, DeMoor RJG, De Witte AMJC, Trimpeneer LM. Fluoride release process of (resin modified) glass-ionomer cements versus (polyacidmodified) composite resins. Biomaterials 1998;19:509-519. 